\title{
Distinctive Electrophoretic Patterns of Esterases from Klebsiella pneumoniae, $K$. oxytoca, Enterobacter aerogenes and $E$. gergoviae
}

\author{
By PH. GOULLET $\dagger$ \\ Laboratoire de Microbiologie, Faculté de Médecine Xavier-Bichat, \\ Université Paris VII, Institut Biomédical des Cordeliers, 21 rue de l'Ecole \\ de Médecine, 75020 Paris Cedex 06, France
}

(Received 5 October 1979)

Esterases of 14 strains of Klebsiella pneumoniae, 14 strains of $K$. oxytoca, 16 strains of Enterobacter aerogenes and 16 strains of E. gergoviae were analysed by horizontal electrophoresis in polyacrylamide-agarose gel. Four principal esterase bands (designated $E_{1}$ to $\mathrm{E}_{4}$ ) and nine minor bands differing in their activity towards synthetic substrates and in their sensitivity to heat and to di-isofluoropropyl phosphate were defined. The comparative distribution of bands showed that the four species analysed were characterized by distinct electrophoretic patterns of their esterases. Band $E_{1}$ was found in all four species, bands $E_{2}$ and $\mathrm{E}_{3}$ only in $K$. oxytoca and band $\mathrm{E}_{4}$ only in some strains of $E$. gergoviae. The apparent molecular weights of esterases $E_{2}$ and $E_{3}$, determined by electrophoresis in a 4 to $30 \%$ polyacrylamide gradient gel, were $58000( \pm 1000)$ and $72000( \pm 1800)$, respectively.

\section{INTRODUCTION}

Klebsiella and Enterobacter species, which are now frequently isolated from nosocomial and opportunistic infections following the widespread use of antibiotics, differ only in a few common biochemical tests. Indole-producing, gelatin-liquefying Klebsiella (K. oxytoca or Bacterium oxytocum) are not given species status in Bergey's Manual of Determinative Bacteriology (Orskov, 1974), but DNA reassociation studies have shown that $K$. pneumoniae and K. oxytoca are different species (Brenner et al., 1977; Jain et al., 1974). The recently described species Enterobacter gergoviae (Richard, 1979; Richard et al., 1976) can be distinguished from $E$. aerogenes by its biochemical reactions. This new species $(E$. gergoviae) is not listed in Bergey's Manual (Buchanan \& Gibbons, 1974).

To improve the phenotypic characterization of these organisms at the molecular level, their esterases were studied by polyacrylamide-agarose gel and polyacrylamide gradient gel electrophoresis.

\section{METHODS}

Bacterial strains. The names and sources of the strains are given in Table 1.

Growth conditions. These were as described previously (Goullet, 1975). Bacteria were harvested during the exponential or stationary phases of growth.

Preparation of extracts. After centrifugation, cells were washed twice with $200 \mathrm{vol} .0 .06 \mathrm{M}$-Tris/glycine buffer $\mathrm{pH} 8.7$, resuspended in an equal volume of the same buffer and disrupted by intermittent sonic oscillation (Sonifier cell disruptor B30, Branson Sonic Power Co., Danbury, Conn., U.S.A.) for 6 min at

$\dagger$ Present address: Laboratoire de Microbiologie, Faculté de Médecine Xavier-Bichat, 16 rue H. Huchard, 75018 Paris, France. 
Table 1. Strains of Klebsiella and Enterobacter examined

\begin{tabular}{|c|c|c|c|c|c|c|}
\hline Code & Organism & Strain* & $\begin{array}{l}\text { Bio- } \\
\text { type }\end{array}$ & $\begin{array}{l}\text { Capsular } \\
\text { antigen } \dagger\end{array}$ & Source + & $\begin{array}{c}\text { Growth } \\
\text { condition(s)\$ } \\
\left(37^{\circ} \mathrm{C}\right)\end{array}$ \\
\hline 1 & $K$. pneumoniae & 413.76 & a & $\mathrm{NC}$ & H. blood, Toulouse & $\mathrm{S}$ \\
\hline 2 & K. pneumoniae & LOU -1.75 & $\mathrm{~b}$ & 3 & H. sputum, Louvain & $\mathrm{S}$ \\
\hline 3 & $K$. pneumoniae & LOU-9.75 & $\mathrm{b}$ & 3 & H. sputum, Louvain & $S$ \\
\hline 4 & $K$. pneumoniae & 645.B.71 & $\mathrm{b}$ & 3 & H. pus, Tangier & S \\
\hline 5 & K. pneumoniae & 502.77 & $\mathrm{~d}$ & 11 & H. blood, Paris & $\mathrm{S}$ \\
\hline 6 & K. pneumoniae & H112.73 & Dc & 3 & H. urine, Paris & $\mathrm{S}$ \\
\hline 7 & $K$. pneumoniae & 1413.70 & & & H. sputum, Tangier & $\mathrm{E}, \mathrm{S}$ \\
\hline 8 & K. pneumoniae & 1332.70 & & & H. urine, Tangier & $\mathrm{S}^{\prime}$ \\
\hline 9 & K. pneumoniae & $1 \mathrm{H} .73$ & & & H. blood, Paris & S \\
\hline 10 & K. pneumoniae & 19B. 74 & & & H. blood, Brussels & $S$ \\
\hline 11 & K. pneumoniae & 39B. 74 & & & H. blood, Brussels & S \\
\hline 12 & $K$. pneumoniae & $17 \mathrm{~L} .74$ & & & H. drain, Louvain & $S$ \\
\hline 13 & $K$. pneumoniae & 11.76 & & & H. faeces, Strasbourg & $S$ \\
\hline 14 & $K$. pneumoniae & 397.76 & & & H. trachea, Paris & \\
\hline 15 & K. oxytoca & 432.76 & Dc & $17(31)$ & H. transplant, Paris & $\mathrm{S}$ \\
\hline 16 & K. oxytoca & 456.77 & Dc & $\mathrm{NC}$ & H. blood, Paris & $S$ \\
\hline 17 & K. oxytoca & 457.77 & Dc & & H. blood, Paris & $\mathbf{S}$ \\
\hline 18 & K. oxytoca & 488.77 & Dc & 47 & H. blood, Paris & $\mathrm{S}$ \\
\hline 19 & K. oxytoca & 493.77 & Dc & $\mathrm{NC}$ & Environmental origin & \\
\hline 20 & K. oxytoca & 443.77 & & & Excipient, Paris & $\mathrm{S}$ \\
\hline 21 & K. oxytoca & 477.71 & & & H. rhinopharynx, Tangier & $\mathrm{S}$ \\
\hline 22 & K. oxytoca & 1021.71 & & & H. urine, Tangier & $\mathrm{E}, \mathrm{S}$ \\
\hline 23 & K. oxytoca & 1204.71 & & & H. sputum, Tangier & $\mathrm{s}$ \\
\hline 24 & K. oxytoca & 92.73 & & & H. urine, Barcelona & $\tilde{S}$ \\
\hline 25 & K. oxytoca & 102.73 & & & H. blood, Barcelona & $S$ \\
\hline 26 & K. oxytoca & 124.73 & & & H. trachea, Paris & $\mathrm{S}$ \\
\hline 27 & K. oxytoca & 48 B. 74 & & & H. blood, Brussels & $\mathrm{S}$ \\
\hline 28 & K. oxytoca & 10.77 & & & H. urine, Lille & S \\
\hline 29 & E. aerogenes & 1.69 & $\mathbf{a}$ & 26 & H. faeces, India & S \\
\hline 30 & E. aerogenes & 4.76 & $\mathrm{a}$ & 68 & $\begin{array}{l}\text { H. sputum, U.S.A., } \\
\text { ATCC } 13048\end{array}$ & $S$ \\
\hline 31 & E. aerogenes & 10.76 & a & 68 & H. urine, Strasbourg & $S$ \\
\hline 32 & E. aerogenes & 1.77 & a & 68 & H. urine, Tangier & S \\
\hline 33 & E. aerogenes & 1.73 & a & $\mathrm{NC}$ & H. pus, Paris & $\mathrm{E}, \mathrm{S}$ \\
\hline 34 & E. aerogenes & 2.70 & b & 26 & H. nasal sample, Tangier & $\mathrm{E}, \mathrm{S}$ \\
\hline 35 & E. aerogenes & 9.76 & $\mathrm{~b}$ & 42 & H. faeces, Gisors & $\mathrm{S}$ \\
\hline 36 & E. aerogenes & 5.75 & $\mathrm{~b}$ & 59 & H. faeces, Château-Gontier & $E, S$ \\
\hline 37 & E. aerogenes & 4.70 & $\mathrm{~b}$ & 68 & H. sputum, Tangier & $\mathrm{E}, \mathrm{S}$ \\
\hline 38 & E. aerogenes & 38.72 & $\mathrm{~b}$ & 68 & H. faeces, Baghdad & $\mathrm{E}, \mathrm{S}$ \\
\hline 39 & E. aerogenes & 2.75 & $\mathrm{~b}$ & 68 & H. sputum, Paris & $\mathrm{E}, \mathrm{S}$ \\
\hline 40 & E. aerogenes & 1.76 & b & 68 & H. blood, Paris & $\mathrm{E}, \mathrm{S}$ \\
\hline 41 & E. aerogenes & 1.70 & b & NC & H. urine, Tangier & E, S \\
\hline 42 & E. aerogenes & 1.72 & $\mathrm{Da}$ & 11 & H. faeces, Toulon & $\mathrm{E}, \mathrm{S}$ \\
\hline 43 & E. aerogenes & 6.75 & $\mathrm{Db}$ & 4 & H. urine, Canada & $E, S$ \\
\hline 44 & E. aerogenes & 11.76 & $\mathrm{Db}$ & 59 & H. sputum, Strasbourg & $S$ \\
\hline 45 & E. gergoviae & 63.72 & & & H. blood, Africa & S \\
\hline 46 & E. gergoviae & 1.73 & & & H. throat, Paris & $\mathrm{E}, \mathrm{S}$ \\
\hline 47 & E. gergoviae & 22.73 & & & H. faeces, Paris & $\mathrm{s}$ \\
\hline 48 & E. gergoviae & 37.73 & & & H. gastric sample, Paris & $\mathbf{S}$ \\
\hline 49 & E. gergoviae & 6.74 & & & H. pus, Paris & $\mathrm{S}$ \\
\hline 50 & E. gergoviae & 16.74 & & & $\begin{array}{l}\text { H. urine, Clermont-Ferrand } \\
\text { (CIP 76.01) }\end{array}$ & S \\
\hline 51 & E. gergoviae & 20.75 & & & H. urine, Clermont-Ferrand & $\mathrm{S}$ \\
\hline 52 & E. gergoviae & 25.75 & & & $\begin{array}{l}\text { H. urine, Clermont-Ferrand } \\
\text { (CIP 76.02) }\end{array}$ & $\mathrm{E}, \mathrm{S}$ \\
\hline 53 & E. gergoviae & 11.76 & & & Environmental origin, Paris & S \\
\hline 54 & E. gergoviae & 12.76 & & & H. pus, Versailles & $E, S$ \\
\hline 55 & E. gergoviae & 1.77 & & & Cosmetic, Paris & $\mathrm{E}, \mathrm{S}$ \\
\hline 56 & E. gergoviae & 2.77 & & & H. pus, CDC Atlanta & $\mathrm{S}$ \\
\hline 57 & E. gergoviae & 3.77 & & & H. blood, CDC Atlanta & $\mathrm{S}$ \\
\hline 58 & E. gergoviae & 5.77 & & & $\begin{array}{l}\text { H. pus abdominal wound, } \\
\text { CDC Atlanta }\end{array}$ & $\mathrm{S}$ \\
\hline 59 & E. gergoviae & 6.77 & & & H. sputum, CDC Atlanta & S \\
\hline 60 & E. gergoviae & 7.77 & & & H. urine, Clermont-Ferrand & $S$ \\
\hline
\end{tabular}

* The strains were provided by Dr C. Richard from the Collection du Service des Entérobactéries de l'Institut Pasteur de Paris (Professeur L. Le Minor) and were grown in L broth (Goullet, 1973).

$\dagger$ According to Richard $(1973,1977)$. NC, No capsule.

$\ddagger$ H, Human origin. ATCC, American Type Culture Collection; CDC, Center for Disease Control; CIP, Collection de l'Institut Pasteur, Paris.

$\S \mathrm{E}$, Bacteria harvested during the exponential phase of growth; $\mathrm{S}$, bacteria harvested during the stationary phase. 


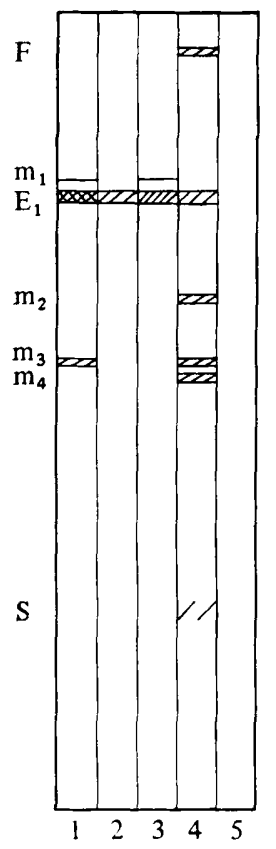

(a)

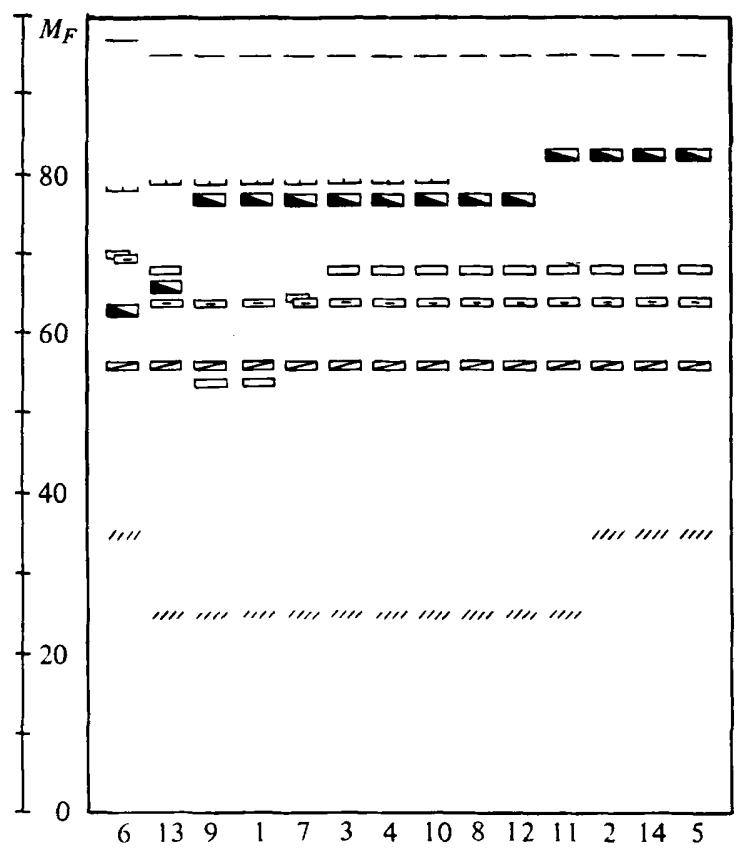

(b)

Fig. 1. Klebsiella pneumoniae. (a) Diagrammatic representation of mobility and activity of esterase bands (strain 1). Horizontal slab polyacrylamide-agarose gel electrophoresis was performed using $7 \%(\mathrm{w} / \mathrm{v})$ acrylamide and discontinuous Tris/glycine buffer, $\mathrm{pH} 8 \cdot 7$. Substrates used were: 1 , $\alpha$-naphthyl acetate; $2, \alpha$-naphthyl butyrate; 3 , indoxyl acetate; $4, \beta$-naphthyl acetate; $5, \beta$-naphthyl butyrate. Relative intensity of staining: $>>\square \square>\square \square>(b)$ Esterase patterns of 14 strains (numbered as in Table 1) arranged in order of increasing mobility of $\mathbf{E}_{1}$ esterase. $\square$, $\mathrm{E}_{1}$ band; $\amalg, \mathrm{m}_{1}$ band; $\square, \mathrm{m}_{2}$ band; $\square, \mathrm{m}_{3}$ band; $\square, \mathrm{m}_{4}$ band; - , $\mathrm{F}$ band; IIII, $\mathrm{S}$ band. The $M_{F}$ values were used only comparatively.

$0{ }^{\circ} \mathrm{C}$. Cell debris was removed by centrifugation at $20000 \mathrm{~g}$ for $20 \mathrm{~min}$ at $4{ }^{\circ} \mathrm{C}$. The crude extracts, containing 40 to $60 \mathrm{mg}$ protein $\mathrm{ml}^{-1}$, were stored at $-25^{\circ} \mathrm{C}$ until use.

Protein estimation. Protein was determined by the biuret method (Gornall et al., 1949) with bovine serum albumin as standard.

Inhibition by di-isofluoropropyl phosphate (DFP). DFP (Sigma) at concentrations between $10^{-5}$ and $10^{-3} \mathrm{M}$ was added to the crude extracts and the mixtures were allowed to stand for $30 \mathrm{~min}$ at room temperature immediately before electrophoresis.

Heat inactivation. Crude extracts mixed with an equal volume of buffer $(0.06 \mathrm{M}$-Tris/glycine pH 8.7$)$ were heated at $60^{\circ} \mathrm{C}$ for $10 \mathrm{~min}$.

Polyacrylamide-agarose gel electrophoresis, estimation of electrophoretic mobility $\left(M_{F}\right.$ value) and esterase staining. These have all been described previously (Goullet, 1975, 1977).

Polyacrylamide gradient gel electrophoresis. Molecular sizes of esterases were investigated by 4 to $30 \%$ (w/v) polyacrylamide gradient gel electrophoresis (Andersson et al., 1972; Margolis \& Kenrick, 1968) using Pharmacia gradient gel PAA $4 / 30$ and Tris $(0.09 \mathrm{M}) /$ borate $(0.08 \mathrm{M}) / \mathrm{Na}_{2}$ EDTA $(0.003 \mathrm{M})$ buffer ( $\mathrm{pH} 8 \cdot 35$ ) without denaturing agents. For molecular weight estimations, bovine serum albumin (Miles, Kankakee, Ill., U.S.A.) and E. coli alkaline phosphatase (Worthington, Freehold, N.J., U.S.A.) were used as reference proteins. Electrophoresis was performed at $5{ }^{\circ} \mathrm{C}$ in the Pharmacia electrophoresis apparatus GE-4. After electrophoresis, gels were stained for esterase activity and bands were marked with a copper wire. Standard proteins were subsequently stained by Coomassie blue. Esterase and protein positions were determined relative to the cathode end of the gel by direct measurement. 


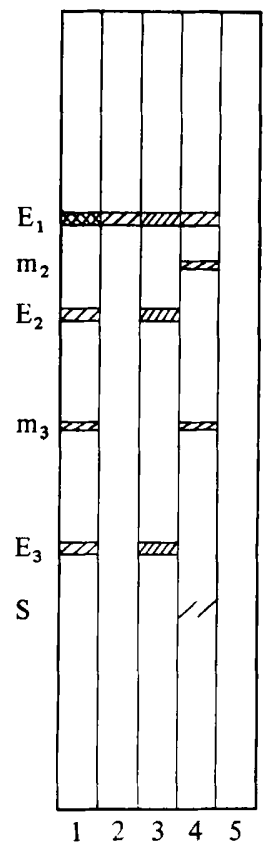

(a)

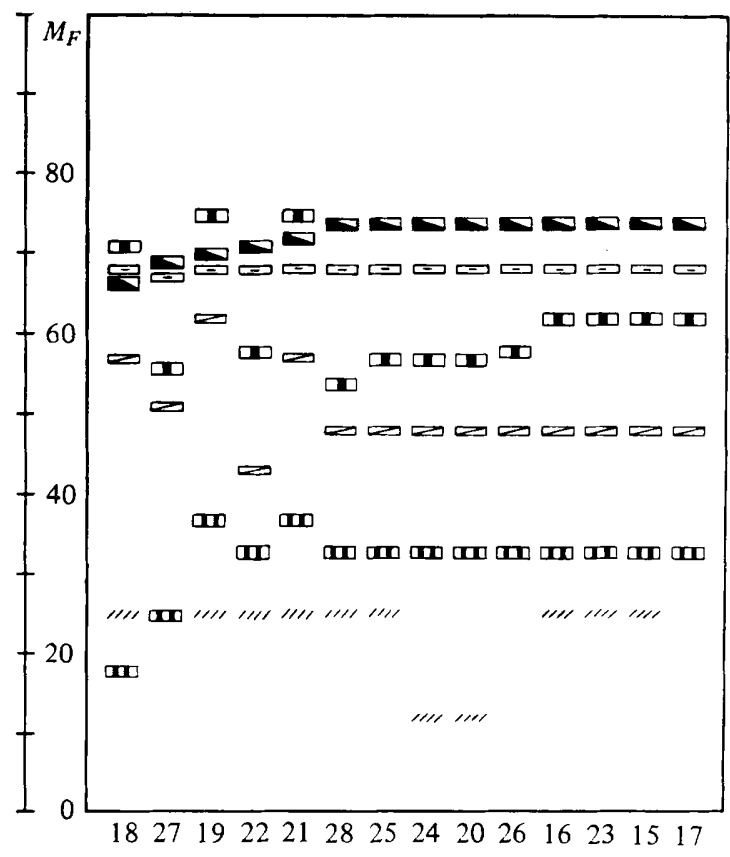

(b)

Fig. 2. Klebsiella oxytoca. (a) Diagrammatic representation of mobility and activity of esterase bands (strain 15). (b) Esterase patterns of 14 strains arranged in order of increasing mobility of $E_{1}$ band. Experimental conditions, relative intensity of staining and key as in legend to Fig. 1. $\square, E_{2}$ band; [U], $\mathrm{E}_{3}$ band.

\section{RESULTS}

\section{Polyacrylamide-agarose gel electrophoresis}

Esterase zymograms gave reproducible patterns characteristic of the four species tested. Electrophoretic relationships between the strains were established by multiple runs comparing esterase bands in adjacent positions on the same gel.

Klebsiella pneumoniae. One major band, designated $\mathrm{E}_{1}$, hydrolysed $\alpha$-naphthyl acetate and, to a lesser degree, indoxyl acetate, $\alpha$-naphthyl butyrate and $\beta$-naphthyl acetate (Fig. 1). This band was inactivated by heat $\left(10 \mathrm{~min}\right.$ at $\left.60^{\circ} \mathrm{C}\right)$ and inhibited by $10^{-4} \mathrm{M}-\mathrm{DFP}$. Four minor bands resistant to $10^{-3} \mathrm{M}$-DFP were also observed: band $\mathrm{m}_{1}$ migrated faster than band $E_{1}$ and was detected by indoxyl and $\alpha$-naphthyl acetates, band $m_{2}$ was detected by $\beta$-naphthyl acetate, band $m_{3}$ was stained by $\alpha$ - and $\beta$-naphthyl acetates and band $m_{4}$ by $\beta$-naphthyl acetate only. Bands $\mathrm{m}_{1}$ and $\mathrm{m}_{2}$ were heat-resistant. Bands $\mathrm{m}_{2}$ and $\mathrm{m}_{4}$ overlapped in strains 6 and 7. The electrophoretic mobility of bands $m_{2}$ and $m_{3}$ showed no 'betweenstrain' variation (with the exception of band $m_{2}$ from strain 6). In addition, two minor bands, $\mathrm{F}$ (fast) and $\mathrm{S}$ (slow), were detected by $\beta$-naphthyl acetate.

Klebsiella oxytoca. Three major bands, designated $\mathrm{E}_{1}, \mathrm{E}_{2}$ and $\mathrm{E}_{3}$ in order of decreasing electrophoretic mobility, hydrolysed indoxyl acetate (Figs 2 and $3 a$ ). Band $\mathrm{E}_{1}$ showed the same esterolytic activity and sensitivity to heat and to DFP as the corresponding band of $K$. pneumoniae. Bands $\mathrm{E}_{2}$ and $\mathrm{E}_{3}$ reacted slightly with $\alpha$-naphthyl acetate. Band $\mathrm{E}_{2}$ resisted $10^{-3} \mathrm{M}$-DFP and band $\mathrm{E}_{3}$ was heat-resistant (Fig. $3 b$ ). Two minor bands, $\mathrm{m}_{2}$ and $\mathrm{m}_{3}$, were similar to those of $K$. pneumoniae. Band $\mathrm{F}$ was not detected.

Enterobacter aerogenes. The major band $\mathrm{E}_{1}$ and minor bands $\mathrm{m}_{2}$ and $\mathrm{m}_{3}$ (Fig. 4) were practically identical to the corresponding bands of $K$. pneumoniae and $K$. oxytoca. A faint 


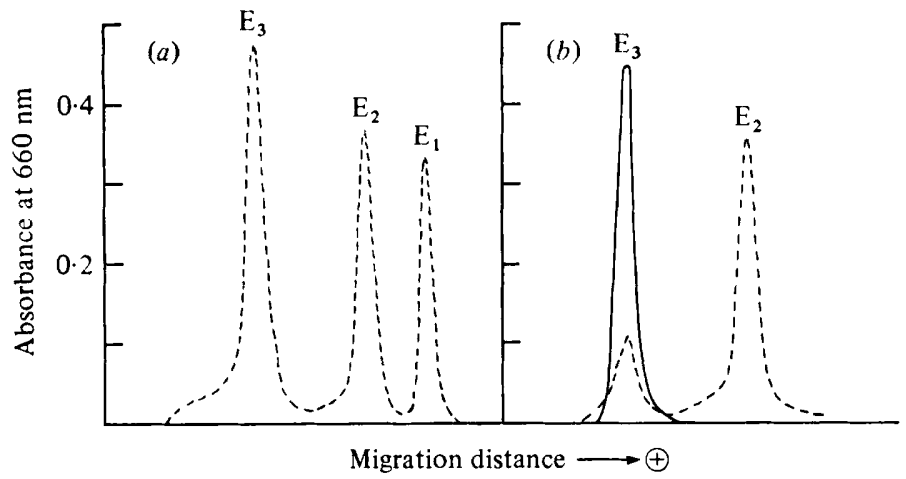

Fig. 3. Effects of heat and DFP on the activity of esterases $E_{1}, E_{2}, E_{3}$ of Klebsiella oxytoca (strain 23). Esterases were stained with indoxyl acetate and scanned at $660 \mathrm{~nm}$. (a) Untreated preparation. (b) Treated preparation: - - , treated with $10^{-3} \mathrm{M}-\mathrm{DFP}$; _- , heated at $60^{\circ} \mathrm{C}$ for $10 \mathrm{~min}$.

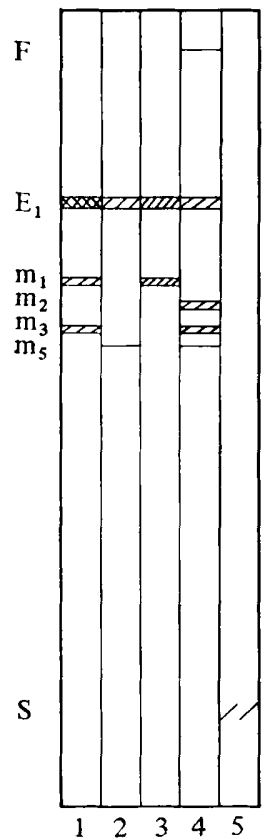

(a)

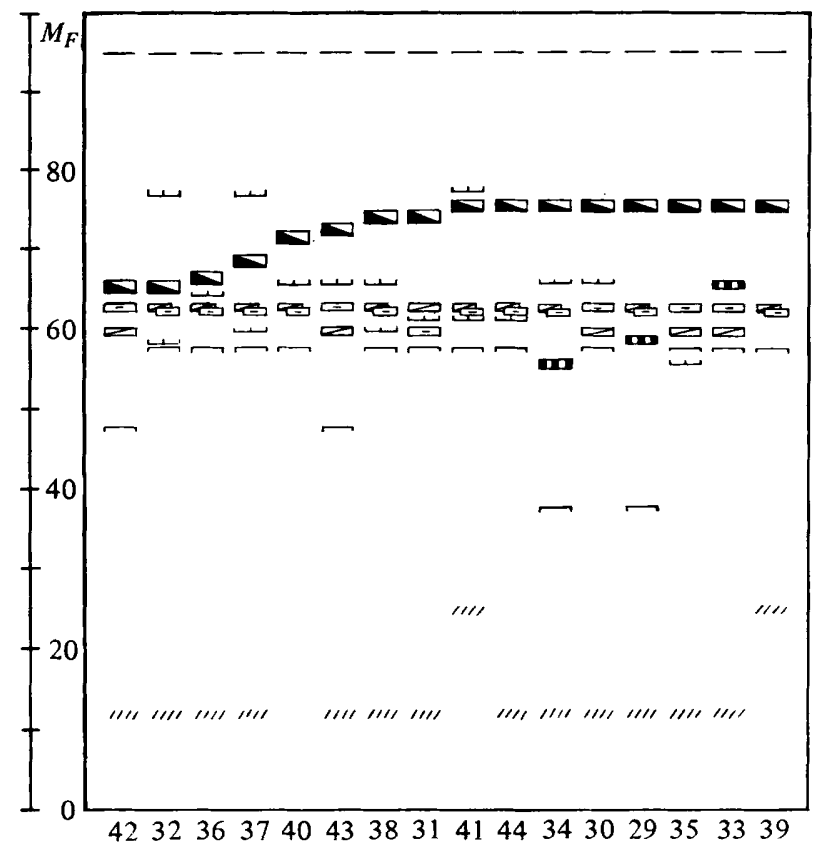

(b)

Fig. 4. Enterobacter aerogenes. (a) Diagrammatic representation of mobility and activity of esterase bands (strain 33). (b) Esterase patterns of 16 strains arranged in order of increasing mobility of $\mathrm{E}_{\mathrm{I}}$ band. Experimental conditions, relative intensity of staining and key as in legend to Fig. 1. UI, band similar to $m_{1}$, but more coloured, for strains 29,33 and $34 ; \neg, m_{5}$ band.

esterase band, $\mathrm{m}_{1}$, hydrolysing indoxyl and $\alpha$-naphthyl acetates and resistant to heat and DFP was similar to that observed in $K$. pneumoniae. An additional band with characteristics similar to $m_{1}$ was observed in strains 29,33 and 34 . Differences in mobility between some minor bands were small and bands $m_{2}$ and $m_{3}$ overlapped in most strains. Separation and characterization of bands were then achieved by varying the concentration of acrylamide and by differential heat inactivation. Band $m_{5}$ reacted weakly with $a$ - and $\beta$-naphthyl butyrates. Band $F$ was very faint. Each of the 16 strains showed a distinct esterase electrophoretic pattern. 


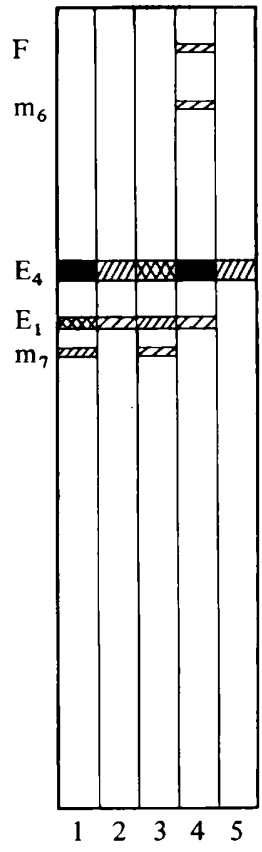

(a)

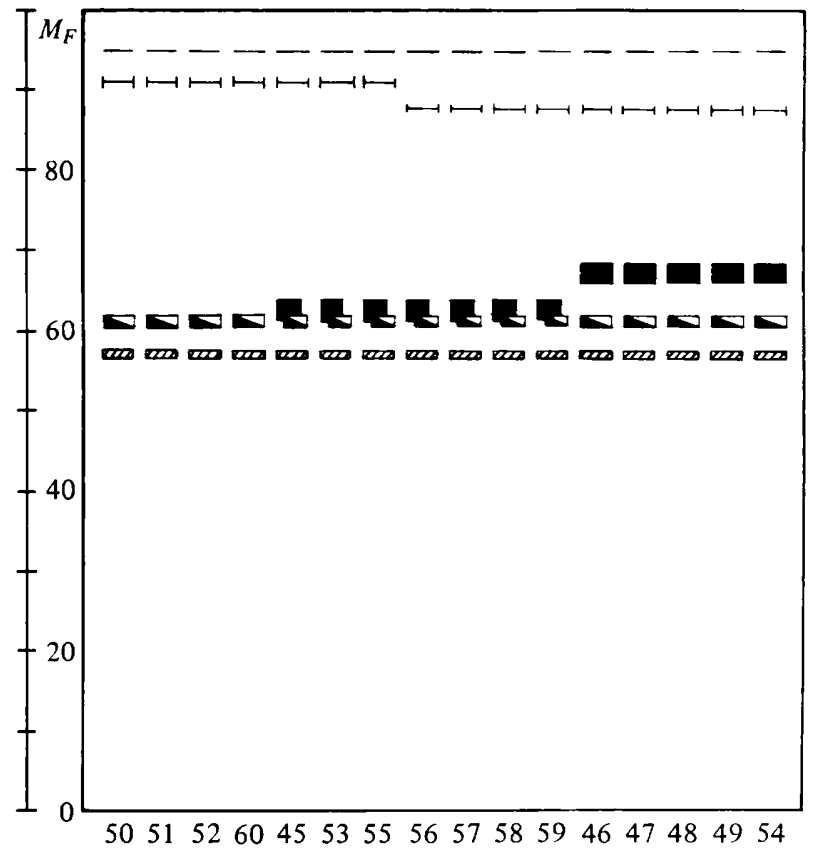

(b)

Fig. 5. Enterobacter gergoviae. (a) Diagrammatic representation of mobility and activity of esterase bands (strain 54). (b) Esterase patterns of 16 strains arranged in order of increasing mobility of $E_{4}$ band. Experimental conditions, relative intensity of staining and key as in legend to Fig. 1.

$\mathrm{E}_{4}$ band;, $\mathrm{m}_{6}$ band; $\mathbb{Z U}, \mathrm{m}_{7}$ band.

Enterobacter gergoviae. Typically, strains of E. gergoviae showed two major esterase bands (Fig. 5): one, designated $E_{1}$, possessed hydrolysing activity similar to that observed in the other three species tested; the second, designated $E_{4}$, showing very strong esterase activity, hydrolysed all five substrates tested and was partially inhibited by $10^{-3} \mathrm{M}$-DFP. Bands $E_{1}$ and $E_{4}$ from strains $45,53,55,56,57,58$ and 59 overlapped when $7 \%$ acrylamide gels were used for electrophoresis but were clearly separated by polyacrylamide gradient gel electrophoresis (see below). Band $\mathrm{E}_{4}$ was not resolved in strains 50,51, 52 and 60 . Two minor bands were resistant to $10^{-3} \mathrm{M}$-DFP - band $\mathrm{m}_{6}$ hydrolysing $\beta$-naphthyl acetate and band $\mathrm{m}_{7}$ hydrolysing $\alpha$-naphthyl and indoxyl acetates. The electrophoretic mobility of bands $\mathrm{E}_{1}\left(M_{F} \approx 60\right)$ and $\mathrm{m}_{7}\left(M_{F^{\prime}} \approx 57\right)$ showed no 'between-strain' variation. In some strains a diffuse band $\left(M_{F} \approx 28\right)$ reacted with all five substrates (not shown).

\section{Polyacrylamide gradient gel electrophoresis}

The major esterases $E_{1}, E_{2}, E_{3}$ and $E_{4}$ were easily detectable in gradient gels by indoxyl acetate. The $\mathrm{E}_{1}$ and $\mathrm{E}_{4}$ bands of $E$. gergoviae, which for some strains overlapped in polyacrylamide-agarose gels, were well separated in polyacrylamide gradient gels. Comparison of electrophoresis for 400,900,1500, 2000 and $2500 \mathrm{~V}$ h showed that asymptotic migration, necessary to determine molecular weight (Rodbard et al., 1971), was obtained for esterases $\mathrm{E}_{2}$ and $\mathrm{E}_{3}$ of $K$. oxytoca (Fig. 6). Using bovine serum albumin and $E$. coli alkaline phosphatase as standard proteins, the molecular weights of esterases $E_{2}$ and $E_{3}$ were estimated to be $58000( \pm 1000)$ and $72000( \pm 1800)$, respectively.

Characteristics of the major bands are summarized in Table 2. 


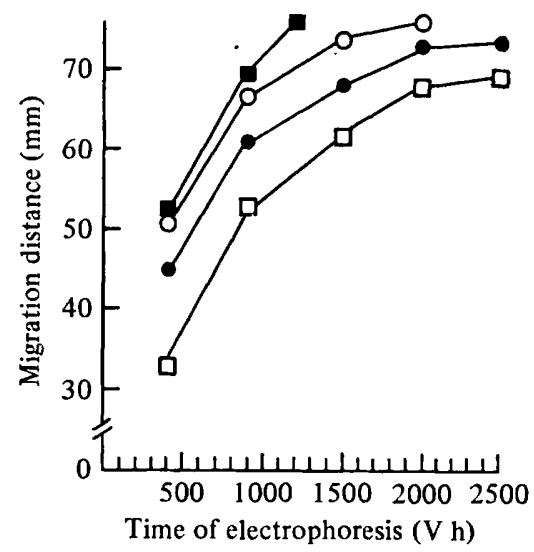

Fig. 6. Plots of mobilities of esterases $E_{1}, E_{2}$ and $E_{3}$ from $K$. oxytoca (strain 23) and esterase $E_{4}$ from $E$. gergoviae (strain 57 ) against time of electrophoresis in a polyacrylamide gradient gel: $O$, esterase $E_{1} ; 0$, esterase $E_{2} ; \square$, esterase $E_{3} ; \square$, esterase $E_{4}$.

Table 2. Characteristics of principal esterase bands of $K$. pneumoniae, $K$. oxytoca, E. aerogenes and E. gergoviae

\begin{tabular}{|c|c|c|c|c|c|c|c|c|}
\hline \multirow[b]{2}{*}{ Band } & \multicolumn{4}{|c|}{ Substrates* hydrolysed $†$} & \multirow{2}{*}{\multicolumn{2}{|c|}{$\begin{array}{l}\text { Inacti- } \\
\text { vation } \dagger \\
\text { after } \\
10 \mathrm{~min} \\
\text { at } 60^{\circ} \mathrm{C}\end{array}$}} & \multirow{2}{*}{$\begin{array}{l}\text { Inhibitory } \\
\text { concn of } \\
\text { DFP (M) }\end{array}$} & \multirow{2}{*}{$\begin{array}{l}\text { Apparent } \\
\text { molecular } \\
\text { weight§ }\end{array}$} \\
\hline & $\alpha \mathrm{NA}$ & $\alpha \mathrm{NB}$ & IA & $\beta$ NA & & & & \\
\hline $\mathrm{E}_{\mathrm{I}}$ & +++ & + & ++ & + & - & - & $10^{-4}$ & \\
\hline $\mathrm{E}_{2}$ & + & - & ++ & - & - & - & R $10^{-3}+$ & $58000 \pm 1000$ \\
\hline $\mathrm{E}_{3}$ & + & - & ++ & - & - & ++ & $10^{-3}$ & $72000 \pm 1800$ \\
\hline $\mathrm{E}_{4}$ & ++++ & ++ & +++ & +++ & ++ & - & $10^{-3}$ & \\
\hline
\end{tabular}

* $\alpha$ NA, $\alpha$-naphthyl acetate; $\alpha \mathrm{NB}, \alpha$-naphthyl butyrate; IA, indoxyl acetate; $\beta \mathrm{NA}, \beta$-naphthyl acetate; $\beta \mathrm{NB}, \beta$-naphthyl butyrate.

,,,+++++++++++ , decreasing intensities of esterase band; - , no activity.

\pm Resistant to $10^{-3}$ M-DFP.

$\S$ Mean \pm s.D.; 6 runs.

Table 3. $M_{F}$ values of esterase bands of $K$. pneumoniae, $K$. oxytoca, $E$. aerogenes and E. gergoviae

Mean $\mathbf{M}_{F}$ values are given together with the standard deviation. Sample sizes are given in parentheses.

\begin{tabular}{|c|c|c|c|c|}
\hline Band & K. pneumoniae & K. oxytoca & E. aerogenes & E. gergoviae \\
\hline $\begin{array}{l}E_{1} \\
E_{2} \\
E_{3}\end{array}$ & $76 \cdot 79 \pm 5 \cdot 80(14)$ & $\begin{array}{l}72 \cdot 50 \pm 2 \cdot 35(14) \\
61 \cdot 86 \pm 6 \cdot 94(14) \\
31 \cdot 93 \pm 4 \cdot 84(14)\end{array}$ & $73 \cdot 13 \pm 3 \cdot 89(16)$ & $60 \cdot 50 \pm 0$ \\
\hline $\mathrm{E}_{4}$ & & & & $64 \cdot 33 \pm 1.97(12)$ \\
\hline $\mathrm{m}_{1}$ & $78 \cdot 88 \pm 0 \cdot 35(8)$ & & $64 \cdot 53 \pm 6 \cdot 55(16)$ & \\
\hline $\mathrm{m}_{2}$ & $64 \cdot 43 \pm 1 \cdot 60(14)$ & $67.93 \pm 0.28(14)$ & $62.81 \pm 0.75(16)$ & \\
\hline$m_{3}$ & $56 \cdot 00 \pm 0$ & $50 \cdot 14 \pm 5 \cdot 02(14)$ & $62 \cdot 06 \pm 1.44(16)$ & \\
\hline $\begin{array}{l}\mathrm{m}_{4} \\
\mathrm{~m}_{5}\end{array}$ & $65 \cdot 86 \pm 5 \cdot 17(14)$ & & $54 \cdot 25 \pm 7 \cdot 19(16)$ & \\
\hline $\mathrm{m}_{6}$ & & & & $89 \cdot 31 \pm 1 \cdot 54(16)$ \\
\hline $\begin{array}{l}\mathrm{m}_{7} \\
\mathrm{~F}\end{array}$ & $95 \cdot 14 \pm 0 \cdot 53(14)$ & & $95 \cdot 00 \pm 0$ & $\begin{array}{ll}57 \cdot 00 \pm 0 \\
95 \cdot 00 \pm 0\end{array}$ \\
\hline $\mathbf{S}$ & $27 \cdot 86 \pm 4 \cdot 69(14)$ & $22 \cdot 64 \pm 5 \cdot 20(11)$ & $13 \cdot 73 \pm 4 \cdot 57(15)$ & \\
\hline
\end{tabular}




\section{DISCUSSION}

Four major esterase bands and nine minor bands were defined from extracts of strains of $K$. pneumoniae, $K$. oxytoca, E. aerogenes and $E$. gergoviae. The distribution of major and minor bands among the strains (Table 3 ) showed that the four species were characterized by distinct esterase patterns. Enterobacter gergoviae exhibited substantial differences from $E$. aerogenes (Table 3). Klebsiella oxytoca differed from $K$. pneumoniae in the presence of major bands $\mathrm{E}_{2}$ and $\mathrm{E}_{3}$ and the absence of bands $\mathrm{m}_{1}, \mathrm{~m}_{4}$ and $\mathrm{F}$, whereas $K$. pnetrmoniae and $E$. aerogenes differed from each other only in two minor bands - band $\mathrm{m}_{4}$ detected in $K$. pneumoniae strains and band $\mathrm{m}_{5}$ detected in $E$. aerogenes strains.

The present study strongly supports the phenotypic individuality of E. gergoviae (Richard, 1979; Richard et al., 1976) and provides new evidence for the differentiation of $K$. oxytoca from K. pneumoniae (Brenner et al., 1977; Gavini et al., 1977; Hugh, 1959; Jain et al., 1974; Lautrop, 1956; Von Riesen, 1976). The similarity of the esterase patterns of $K$. pneumoniae and E. aerogenes correlates well with the biochemical and serological similarities of these two species (Bascomb et al., 1971; Johnson et al., 1975; Richard, 1977; Steffen et al., 1972).

The author thanks Dr C. Richard for Klebsiella and Enterobacter strains, and Madame Colette Gaillard and Mademoiselle Catherine Lamesch for technical assistance. This work was supported by grants from the Universite de Paris VII and from the Institut National de la Santé et de la Recherche Médicale (no. 78.1.136.1).

\section{REFERENCES}

Andersson, L. O., Borg, H. \& Mikaelsson, M. (1972). Molecular weight estimations of proteins by electrophoresis in polyacrylamide gels of graded porosity. FEBS Letters 20, 199-202.

Bascomb, S., Lapage, S. P., Willcox, W. R. \& Curtis, M. A. (1971). Numerical classification of the tribe Klebsielleae. Journal of General Microbiology 66, 279-295.

BrenNer, D. J., FARMer, J. J., Hickman, F. W., Asbury, M. A. \& Steigerwalt, A. G. (1977). Taxonomic and nomenclature changes in Enterobacteriaceae. Center for Disease Control, Department of Health, Education and Welfare, Publication No. 78-8356. Atlanta, Georgia, U.S.A.: C.D.C.

Buchanan, R. E. \& Gibbons, N. E. (editors) (1974). Bergey's Manual of Determinative Bacteriology, 8th edn. Baltimore: Williams \& Wilkins.

Gavini, F., Leclerc, H., Lefebvre, B., Ferragut, C. \& IZARD, D. (1977). Etude taxonomique d'Enterobactéries appartenant ou apparentées au genre Klebsiella. Annales de Microbiologie 128B, 45-49.

Gornall, A. G., Bardawill, D. J. \& David, M. M. (1949). Determination of serum proteins by means of the biuret reaction. Journal of Biological Chemistry 177, 751-766.

Goullet, PH. (1975). Esterase zymograms of Proteus and Providencia. Journal of General Microbiology 87, 97-106.

Goullet, PH. (1977). Relationships between electrophoretic patterns of esterases from Salmonella. Journal of General Microbiology 98, 535-542.

HuGH, R. (1959). Oxytoca group organisms isolated from the oropharyngeal region. Canadian Journal of Microbiology 5, 251-254.
JAIN, K., RADSAK, K. \& MANnheim, W. (1974). Differentiation of the Oxytocum group from Klebsiella by deoxyribonucleic acid-deoxyribonucleic acid hybridization. International Journal of Systematic Bacteriology 24, 402-407.

Johnson, R., Colwell, R. R., SAKAzakı, R. \& TAMURA, K. (1975). Numerical taxonomy study of the Enterobacteriaceae. International Journal of Systematic Bacteriology 25, 12-37.

LAUTROP, H. (1956). Gelatin-liquefying Klebsiella strains (Bacterium oxytocum (Flüggel)). Acta pathologica et microbiologica scandinavica 39, 375-384.

Margolis, J. \& Kenrick, K. G. (1968). Polyacrylamide gel electrophoresis in a continuous molecular sieve gradient. Analytical Biochemistiy 25, 347-362.

Orskov, I. (1974). Genus VI Klebsiella Trevisan 1885. In Bergey's Manual of Determinative Bacteriology, 8th edn, pp. 321-324. Edited by R. E. Buchanan \& N. E. Gibbons. Baltimore: Williams \& Wilkins.

Richard, C. (1973). Etude antigénique et biochimique de 500 souches de Klebsiella. Annales de biologie clinique 31, 295-303.

RichaRd, C. (1977). Présence chez Enterobacter aerogenes d'antigènes capsulaires apparentés à ceux de Klebsiella: intérêt de l'utilisation du métahydroxybenzoate dans le diagnostic différentiel E. aerogenes - K. pneumoniae. Annales de Microbiologie 128A, 289-295.

RiCHARD, C. (1979). Entérobactéries inhabituelles. Bulletin de l'Institut Pasteur 77, 83-98.

Richard, C., Joly, B., Sirot, J., Stoleru, G. H. \& Popoff, M. (1976). Etude de souches d'Entero- 
bacter appartenant à un groupe particulier proche de E. aerogenes. Annales de Microbiologie 127A, 545-548.

Rodbard, D., Kapadia, G. \& Chrambach, A. (1971). Pore gradient electrophoresis. Analytical Biochemistry 40, 135-157.

Steffen, D. L., Cocks, G. T. \& Wilson, A. C.
(1972). Micro-complement fixation in Klebsiella classification. Journal of Bacteriology 110, 803-808. VON RIESEN, V. L. (1976). Pectinolytic, indolepositive strains of Klebsiella pneumoniae. International Journal of Systematic Bacteriology 26, 143-145. 